\title{
Social Responsibility: As a Predictor of Altruistic Personality among Adults
}

\author{
Misha Aziz ${ }^{1}$ and Momina Abid ${ }^{2 *}$ \\ ${ }^{1}$ Department of Applied Psychology, Bahauddin Zakariya University, Multan \\ ${ }^{2}$ Psychologists, Special Education Department, Government of the Punjab, Pakistan
}

Submission: February 24, 2018; Published: March 22, 2018

*Corresponding author: Momina Abid, Psychologists, Special Education Department, Government of the Punjab, Pakistan; Email: Mominaabid11@gmail.com

\section{Abstract}

Social responsibility and altruistic behavior seems to be a part of human nature but it varies in individual in so many contexts. Altruistic behavior makes person personality altruistic. Present study was purposed to explore the predictive relationship between social responsibility and altruistic personality. Randomly selected a sample of 150 adults in which 63 was males and 87 was females. The Altruistic Personality Scale and social responsibility scale were used in this study. Findings indicated that social responsibility has significant positive relationship with altruistic personality. Regression analysis reveals that socially responsibility had significant impact on altruistic personality. Findings also indicated that significant gender differences on altruistic personality but no significant gender differences on socially responsibility among adults

Keywords: Social responsibility, Altruistic Personality, Altruistic Behavior, Prosocial Behaviors, Adults

Abbreviations: SR: Social Responsibility; EC: Empathic Concern; PT: Perspective Taking; PD: Personal Distress; O: Other-Oriented Moral Reasoning; M: Mutual Concerns moral reasoning; SRA: Self-reported altruism

\section{Introduction}

Social responsibility is one type of prosocial behavior. An individual takes an actions to help others is kwon as prosocial behavior and one possible motivation for those actions is kwon as altruism. Social Responsibility means that people and organizations must perform morally and with kindness toward cultural, social, environmental, economic problems. Social responsibility helps organizations, governments and individuals have a positive impact on society, business and development with a positive input to outcome results. Socially responsible action respectively actions in terms of sustainability are seen as moral judgment and actions that may be largely affected by emotional components Kals Maes 2002. Social responsibility as a personal variable is linked to the willingness to act in a reliable and a fair way of personal commitment toward legitimate expectations of others Bierhoff [1].

According to Batson, Bolen, Cross and Benefiel 1986 there has been substantial dispute about whether or not there is an altruistic personality. Incorporated among personality variables significant to the idea of an altruistic nature are other-oriented cognitive and emotional tendencies such as sympathy (i.e., other-oriented concern or sorrow for another), attribution of responsibility, perspective taking (i.e., understanding another's cognitive point of view or affective situation) and social responsibility Staub [2]; Rushton 1980; Batson et al. [3]; Schwartz, Howard [4]. Numerous studies identified that social responsibility and empathic nature are the interior variables of the altruistic personality Bierhoff [5]. Exclusively, the postulation of an altruistic personality is based on the probability that those people who score high on empathic tendency also score high on social responsibility. According to the altruistic personality assumption, experimental studies show that the altruistic personality predicts prosocial behavior in the laboratory Staub [2] as well as in the field Bierhoff [6]; Oliner [7]; Omoto, Snyder [8]; Penner, Finkelstein [9].

Carlo [10] investigated that prosocial behavior could be significantly predicted in adults when they could easily escape form situation without helping and when the desire for help was high by social responsibility. Berkowitz [11] demonstrate that when the norms of social responsibility have been made prominent then social responsibility was positively correlated with helping on the basis of individual differences in variables. In addition, Staub [2] revealed the significance of the prosocial personality, which shows that in general that the prosocial personality is a feasible concept and exclusively that the social responsibility scale and prosocial behavior are positively correlated. Referring to the altruistic personality, Batson, Bolen, 
Cross, and Neuringer-Benefiel 1986 assumed that under difficultescape circumstances a positive correlation with measures of the altruistic personality would occur and an intensive goal of the observer is operative that is avoidance of guilt and shame. The aim of this study is to assess social responsibility as a predictor of altruistic personality among adults. Social responsibility and altruistic personality are important concepts in social psychology.

\section{Objectives}

a) To examine the relationship between altruistic personality and social responsibility among adults.

b) To examine the impact of altruistic personality on social responsibility among adults.

c) To examine the gender differences of altruistic personality and social responsibility among adults.

\section{Hypothesis}

a) There will be positive correlation between social responsibility and altruistic personalityamong adults.

b) Social responsibility has significant impact on altruistic personalityamong adults.

c) Social responsibility and altruistic personality will vary in term of gender among adults.

\section{Method}

\section{Participants}

150 participants (63 males and 87 females) adults were taken through convenient sampling. Participant were included in the study those willing to be a part of the study.

\section{Instruments}

Two instruments altruistic personality scale and prosocial personality battery were used in this study.

\section{Altruistic Personality Scale}

The Altruistic Personality Scale Rushton 1981 was developed to measure the level of altruistic personality. It has 20-item that is designed to measure altruistic tendency by gauging the frequency one engages in altruistic acts primarily toward strangers. It is based on 5-point scale ranging from Never (0) to Very Often (4).

\section{Prosocial Personality Battery}

Prosocial Personality Battery is firstly created by Penner [9]. It has 30-item. It has seven subscales. In present research one subscale of social responsibility was used. The prosocial personality battery has further seven scales which are Social Responsibility (SR), Empathic Concern (EC), Perspective Taking (PT), Personal Distress (PD), Other-Oriented Moral Reasoning (0), Mutual Concerns moral reasoning (M), Self-reported altruism (SRA). Social responsibility (SR) is measured from seven questions which are 1 . When people are nasty to me, I feel very little responsibility to treat them well. (R) 2. I would feel less bothered about leaving litter in a dirty park than in a clean one. (R) 3. No matter what a person has done to us, there is no excuse for taking advantage of them. 4 . With the pressure for grades and the widespread cheating in school nowadays, the individual who cheats occasionally is not really as much at fault. (R) 5. It doesn't make much sense to be very concerned about how we act when we are sick and feeling miserable. (R) 6. If I broke a machine through mishandling, I would feel less guilty if it was already damaged before I used it. (R) 7. When you have a job to do, it is impossible to look out for everybody's best interest. (R) With reverse scoring of item number 1, 2, 4,5,6,7.

\section{Procedure}

Data was collected through survey questionnaire social responsibility and altruistic personality scale. Participants were conveniently selected and The Altruistic Personality Scale (Rushton, Chrisjohn \& Fekken, 1981) and social responsibility scale subscale of Prosocial Behavior Battery (Penner, 2002) were used in present research. All the instructions were provided to participants about all the purposes of the research and participants were urged to answer all the items honestly and answers were remaining anonymous. SPSS (Statistical Package of Social Sciences) has been used for the analysis of data collected from participants.

\section{Result}

Table 1 shows that significant positive correlation between social responsibility and altruistic personality. Values indicate that social responsibility has positive correlation with altruistic personality.

Table 1: Correlations Matrix on the scores of Social Responsibility and Altruistic Personality.

\begin{tabular}{|c|c|c|}
\hline Scale & $\begin{array}{c}\text { Social } \\
\text { Responsibility }\end{array}$ & $\begin{array}{c}\text { Altruistic } \\
\text { Personality }\end{array}$ \\
\hline Social Responsibility & 1 & $.195^{*}$ \\
\hline Altruistic Personality & & 1 \\
\hline
\end{tabular}

Note: $\mathrm{N}=150^{*} \mathrm{p}<0.05$

Table 2: Regression Analysis showing Impact of Social Responsibility on Altruistic Personality.

\begin{tabular}{|c|c|c|c|c|c|}
\hline Predictor & $\mathbf{B}$ & $\begin{array}{c}\text { Std. } \\
\text { Error }\end{array}$ & $\boldsymbol{\beta}$ & $\mathbf{t}$ & $\mathbf{p}$ \\
\hline (Constant) & 17.493 & 1.343 & & 13.022 & $.000^{* * *}$ \\
\hline $\begin{array}{c}\text { Altruistic } \\
\text { Personality }\end{array}$ & .063 & .026 & .195 & 2.423 & $.017^{*}$ \\
\hline
\end{tabular}

Note. $R^{2}=0.038$, Adjusted $R^{2}=0.032,\left(F(1,148)=5.870,{ }^{* * *} p<\right.$ $0.001,{ }^{*} \mathrm{p}<0.05$

Table 2 regression analyses revealed that social responsibility have significant impact on altruistic personality. 


\section{Psychology and Behavioral Science International Journal}

Table 3: Mean, Standard deviation, and $t$ value for the score of gender differences among altruistic personality.

\begin{tabular}{|c|c|c|c|c|c|c|}
\hline Gender & $\mathbf{N}$ & $\mathbf{M}$ & $\mathbf{S D}$ & $\mathbf{t}(\mathbf{1 4 8 )}$ & $\mathbf{P}$ & Cohen's d \\
\hline Male & 63 & 53.81 & 11.638 & & & \\
\hline & & & & 3.082 & $.002^{*}$ & 0.504 \\
\hline Female & 87 & 48.34 & 10.002 & & & \\
\hline
\end{tabular}

Note: $\mathrm{N}=150,{ }^{*} \mathrm{p}<0.05$

Table 3 indicates that $\mathrm{p}$ value is less than 0.05 and indicates the difference in the level of altruistic personality among adults. Results indicate that level of altruistic personality is varying in term of gender. It also shows that men are more altruistic than females. It accepted hypothesis.

Table 4: Mean, Standard deviation, and $t$ value for the score of gender differences among Social Responsibility.

\begin{tabular}{|c|c|c|c|c|c|c|}
\hline Gender & $\mathbf{N}$ & $\mathbf{M}$ & $\mathbf{S D}$ & $\mathbf{t}(\mathbf{1 4 8 )}$ & $\mathbf{P}$ & $\begin{array}{c}\text { Cohen's } \\
\mathbf{d}\end{array}$ \\
\hline Male & 63 & 20.81 & 3.412 & & & \\
\hline & & & & .399 & .690 & 0.067 \\
\hline Female & 87 & 20.57 & 3.652 & & & \\
\hline
\end{tabular}

Note: $\mathrm{N}=150, \mathrm{p}>0.05$

Table 4 indicate that $\mathrm{p}$ value is greater than 0.05 and indicate that no difference in the level of social responsibility among adults. Results indicate that level of social responsibility have no differences among male and female adults. It rejected hypothesis Figure 1.

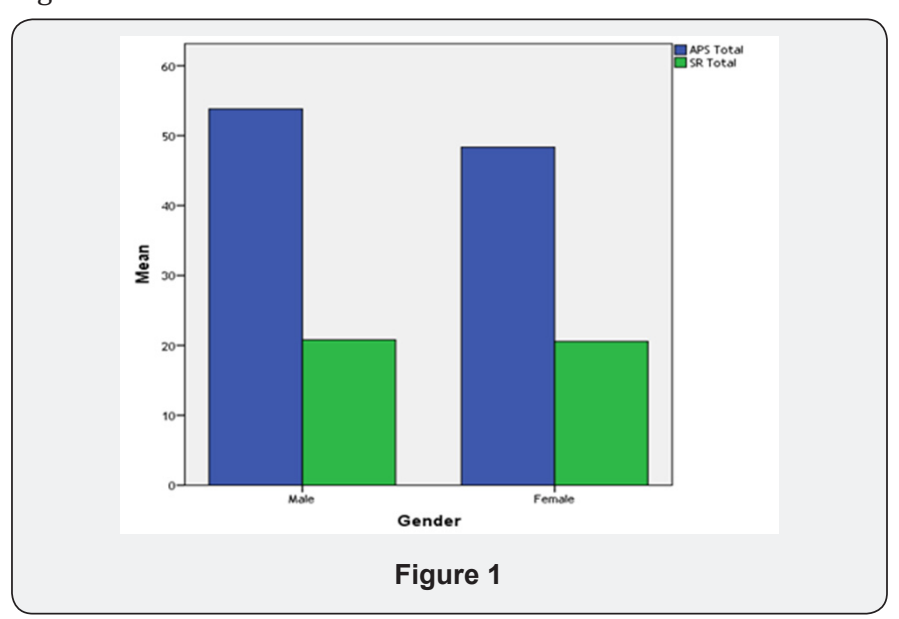

\section{Discussion}

The present study was conducted to examine the association between social responsibility and altruistic personality among adults. Social responsibility and altruistic behavior seems to be a part of human nature but it varies in individual in so many contexts. They vary when escape was difficult. First, it is important to recognize that we confirmed the first hypothesis which is "There will be positive correlation between social responsibility and altruistic personality" the Table 1 depicts that there is a significant positive correlation between social responsibility and altruistic personality. This reveals that as social responsibility increases the altruistic personality will increase. Current findings are in line with previous study by Batson et al. (1986) explored that people shows positive relation between altruistic personality and helping when escape was difficult. Second hypothesis of the current study was that "Social Responsibility has significant impact on Altruistic Personality" the regression analysis in Table 2 reveals that social responsibility has significant impact on altruistic personality. This means that if a person is more socially responsible than individual shows higher level of altruistic personality.

Third hypothesis says that "Social Responsibility and Altruistic Personality will vary in term of gender." The Table 3 Results indicates that level of altruistic personality is varying in term of gender. It also shows that men are more altruistic than females. But there is no significant difference on the level of social responsibility.

\section{Conclusion}

The present study concluded that social responsibility as a predictor of altruistic personality. Findings of this study revealed that there is significant positive correlation between social responsibility and altruistic personality. Those people who are more socially responsible show more altruism in their daily life. And social responsibility has an impact on altruistic personality this means if a person is more socially responsible than he shows higher level of altruistic personality. There are also significant gender differences in altruistic personality. Men show more altruistic personality and then females.

\section{References}

1. Bierhoff HW (2000) Skala der sozialen Verantwortungnach Berkowitz and Daniels Entwicklung und Validierung, Diagnostica 46:18-28.

2. Staub E (1974) Helping a distressed person: Social, personality, and stimulus determinants. In L Berkowitz (Eds.), Advances in experimental social psychology. Academic Press, New York, USA.

3. Batson CD, Bolen MH, Cross JA, Neuringer-Benefiel HE (1986) Where is the altruism in the altruistic personality? Journal of Personality and Social Psychology 50: 212-220.

4. Schwartz SH, Howard JA (1984) Internalized values as motivators of altruism. In E Staub, D Bar-Tal, J Karylowski, J Reykowski (Eds.), The development and maintenance of prosocial behavior: International perspectives on positive development, Plenum Press, New York, USA, pp. 229-255.

5. Bierhoff HW (2002) Prosocial behavior. Psychology, Hove, UK.

6. Bierhoff HW, Klein R, Kramp P (1991) Evidence for the altruistic personality from data on accident research. Journal of Personality 59(2): 263-280.

7. Oliner SP, Oliner PM (1988) The altruistic personality. Rescuers of Jews in Nazi Europe. Free Press, New York, USA.

8. Omoto AM, Snyder M (1995) Sustained helping without obligation: Motivation, longevity of service, and perceived attitude change among AIDS volunteers. J Pers Soc Psycho 68(4): 671-686.

9. Penner LA, Finkelstein MA (1998) Dispositional and structural determinants of volunteerism. Journal of Personality and Social Psychology 74(2): 525-537. 
10. Berkowitz L, Daniels LR (1964) Affecting the salience of the social responsibility norm: Effects of past help on the response to dependency relationships. Journal of Abnormal and Social Psychology 68: 275-281.

This work is licensed under Creative Commons Attribution 4.0 License

DOI: $10.19080 /$ PBSIJ.2018.08.555746
11. Carlo G, Eisenberg N, Troyer D, Switzer G, Speer AL (1991) The altruistic personality: In what contexts is it apparent? Journal of Personality and Social Psychology 61: 450-458.

\section{Your next submission with Juniper Publishers will reach you the below assets}

- Quality Editorial service

- Swift Peer Review

- Reprints availability

- E-prints Service

- Manuscript Podcast for convenient understanding

- Global attainment for your research

- Manuscript accessibility in different formats ( Pdf, E-pub, Full Text, Audio)

- Unceasing customer service

Track the below URL for one-step submission https://juniperpublishers.com/online-submission.php 